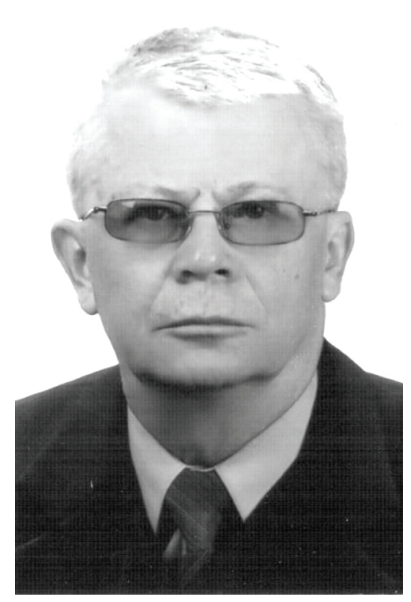

Waldemar Rezmer - Torunès Mikalojaus Koperniko universiteto Politikos mokslų ir saugumo studiju fakulteto profesorius

Moksliniai interesai: karo istorija, šiuolaikinè istorija ir saugumo studijos El.paštas:wre@umk.pl

Waldemar Rezmer - University Professor at the Faculty of Political Science and Security Studies of Nicolaus Copernicus University in Toruń Research interests: Military History, Contemporary History and Security Studies E-mail:wre@umk.pl

\title{
Waldemar Rezmer
}

\section{WOMEN AND SOLDIERS IN THE WAR OF POLISH-LITHUANIAN INTELLIGENCE OF 1920 TO 1939}

\begin{abstract}
The Polish-Lithuanian conflict did not die down in the autumn of 1920 after the termination of bloody fighting, but instead persisted. However, from then on, the conflict continued mainly at the diplomatic level, in propaganda, and in the operations of the secret services: subversive and sabotage-related activities, propaganda-based subversion, disinformation and intelligence-related activities. On the Polish side, these activities were conducted by agencies of the Second Department of the General Staff (Central Headquarters) of the Polish army, and on the Lithuanian side by the Intelligence (Information) Department of the General Staff (Supreme Staff). A distinctive feature of Lithuanian intelligence directed against Poland was the substantial involvement of women, and using Lithuanians who were citizens of the Second Polish Republic doing their mandatory military service in the Polish army. The most costly victories over Polish intelligence were attributed to women agents of Lithuanian intelligence.

KEY WORDS: Lithuanian intelligence, Polish intelligence, Second Department of Polish General Staff, Branch No 1 of the Second Department in Vilnius, Lithuanians in the Polish army.

DOI: http://dx.doi.org/10.15181/rh.v28i0.2236

The main military authorities of the Second Polish Republic strove to be as reliably informed as possible about the political, military, economic, social, ethnic and religious situations of its neighbours, especially when they might pose a threat to its territorial integrity and its internal and external security. However, the unfolding situation in other European countries was also of interest to the
\end{abstract}


Second Polish Republic, because an awareness of their external and internal policies, and of their military and economic potential, facilitated representing and securing the interests of Poland and its citizens abroad. It also facilitated taking effective information and propaganda-related actions, as well as supporting and securing Polish economic interests, while strengthening cooperation with Poles living abroad.

There is a set of records in the Central Military Archives in Warsaw of the Second Department of General Staff (from 1928 onwards, of the Supreme Staff) of the Polish army, with 7,838 archival records. ${ }^{1}$ This is the largest collection of records of Polish intelligence in the interwar period. The majority are documents of the Second Department transported from Warsaw by the Germans, only to be found after the Second World War in Gdańsk-Oliwa, and reclaimed in the Sixties from the archives of the USSR, and eventually repossessed from archive institutions of the Ministry of Internal Affairs operating under the People's Republic of Poland and from the Military Information Services.

The archive materials were amassed in the interwar period by branches dealing with internal and external intelligence, with counter-intelligence, behind the lines sabotage, cryptography, and the analysis of foreign armed forces and military foreign affairs. They paid much attention to the most dangerous neighbours of Poland: Soviet Russia (the USSR) and the Weimar Republic (the Third Reich). Information was collected applying all possible methods and using all possible sources, whether legal or involving the secret services. The information in question was provided by units of the Second Department and branches of the Ministry of Internal Affairs (Civil Police, ${ }^{2}$ Border Patrol ${ }^{3}$ and Border Protection Corps ${ }^{4}$ ), the Ministry of Foreign Affairs, ${ }^{5}$ and other ministries. Many pieces of information were acquired by Polish intelligence thanks to its cooperation with the secret services of other countries. Its cooperation with Romania, France and the Baltic countries (Latvia, Estonia and Finland) was rather close and systematic. On the other hand, its cooperation with some partners (such as Japan, Turkey and Persia) was only occasional.

Informator o zasobie archiwalnym Centralnego Archiwum Wojskowego. ed. N. Bujniewicz, Warszawa 2008, p. 71.

2 For more on this issue, see: A. Misiuk, Policja Państwowa 1919-1939. Powstanie organizacja kierunki działania, Warszawa 1996; H. Skrzeczowski, Współdziałanie wojskowych służb informacyjnych z Policją Państwową w II Rzeczypospolitej, Toruń 2002.

3 H. Dominiczak, Granica wschodnia Rzeczypospolitej Polskiej w latach 1919-1939, Warszawa 1992.

${ }^{4}$ For more comprehensive treatment of this issue, see: M. Jabłonowski, J. Prochwicz, Wywiad Korpusu Ochrony Pogranicza 1924-1939, Warszawa 2003/2004.

5 A. Pepłoński, Wywiad a dyplomacja II Rzeczypospolitej, Toruń 2004. 
Apart from reports by Polish civilians and military diplomats, and the material acquired via traditional covert human intelligence, the national and local press, and all sorts of publications issued in states of interest to Polish intelligence, were permanently analysed.

Despatches, reports and notifications were subsequently analysed in the Second Department, and all sorts of reports, accounts, statements, notices and lists, as well as data, were drafted. Attention was paid not only to military issues, but also to political, economic, social, ethnic and religious issues. The condition of railway, road and water transport, the living conditions of local inhabitants, and the public mood, were also taken heed of. Some of the most important documents studied by the staff of the Second Department were the regularly issued Komunikaty Informacyjne (Information Notes). The bulletin first had a wide circulation, it went to many people in senior military positions and nonmilitary posts responsible for external and internal security-related issues. From 1926, the circulation was more limited. Komunikat Informacyiny reached only those in the most important positions in the armed forces; for example, among others, the minister and vice-ministers of military affairs, the general inspector of the armed forces, the inspector of the army, the chief of the General Staff (Supreme), his deputies, the chiefs of particular departments of the General Staff, corps district commanders, the chief of Navy Command, and, for internal purposes, the Second Department of the General Staff.

A territorial conflict over the Vilnius region (Vilniaus kraštas) and the Suwałki region (Suvalku kraštas) made it the case that throughout the interwar period, Polish intelligence also watched Lithuania, its southeast neighbour, closely. What aroused special interest was Lithuania's military (and war-related) potential, its internal political and socio-economic situation, and its actions in the international arena. However, acquiring information presented many problems. The main burden, therefore, was the absence, up to the spring of 1938, of Polish diplomatic representation and of a military attaché there. Neither were there other official or semi-official representations, such as trade, telecommunications, press-related or cultural ones. The lack of legal and official access to original Lithuanian sources, whether governmental, military, administrative or economic, forced information to be acquired in a direct way, by taking advantage of representatives of other countries accredited in Kaunas. Relevant information was also provided by Polish diplomatic missions in states neighbouring the Republic of Lithuania. What played a particularly significant role were the representation in Riga and the consulates in Daugavpils and Liepāja in Latvia, and consulates in Kaliningrad and Olsztyn in German East Prussia. ${ }^{6}$ In Riga, there

${ }^{6}$ W. Skóra Wojciech, Służba konsularna Drugiej Rzeczypospolitej. Organizacja, kadry i działalność, Toruń 2006, p. 884. 
was an accredited Polish military attaché, whose task, apart from collecting information on Soviet Russia, was also to observe Lithuania. He kept in touch with officers of Latvian intelligence, and received relevant information from them. He subsequently forwarded the information to Warsaw. For instance, in 1925, the information in question was equivalent to material illustrating fighting the communist movement in Lithuania. ${ }^{7}$

Traditional covert human intelligence obtained by branches and intelligence posts of the Second Department of the General Staff and those under the Ministry of Internal Affairs was also made use of: the Civil Police (especially the police stations in Suwałki, Grodno, Białystok, Švenčionys, Vilnius, Trakai and Braslaw), Border Patrol, and Border Protection Corps, from 1924 responsible for the security of the eastern border of the Second Polish Republic. ${ }^{8}$

What follows from the analysis of the preserved documents of the Second Department of the General Staff is that the greatest number of the most significant documents pertaining to Lithuania was provided by Vilnius Branch No 1. The reason is that it had at its disposal a large network of stationary and mobile agents and intelligence posts. Branch No 1 in Vilnius cooperated closely with the intelligence spot 'Nord', located in Riga, the centre of attention of which was, apart from Soviet Russia, northern Lithuania. From the mid-1920s, Branch No 1 took advantage of the assistance provided by the Intelligence Agency of the 6th Brigade of the Border Protection Corps (KOP) in Druskininkai, the latter being oriented towards the observation of areas around the border. Its operations were exceptionally effective. After all, the KOP secret service network had numerous agents and informers. ${ }^{9}$ An agent was a person who, either for money or not, deliberately shared relevant information, with their cooperation with an intelligence body being permanent or supposed to be permanent. In short, the main difference between an agent and an informer consisted of the fact that the agent provided his services continuously, with his work being somehow guided, whereas the services provided by an informer were only used on an interim basis.

A substantial obstacle to the functioning of the Polish Intelligence Agency was the fact that martial law was in place in the Republic of Lithuania until the summer of 1926 . Broad prerogatives granted at that time to the Lithuanian se-

7 See, for example: Centralne Archiwum Wojskowe (CAW), Oddział II Sztabu Generalnego [Central Military Archives, the Second Department of the General Staff] (Oddz. II Szt. Gen.), sygn. [reference symbol of the documents] I.303.4.1772.

8 For more on this issue, see: M. Jabłonowski, J. Prochwicz, Wywiad Korpusu Ochrony Pogranicza 1924-1939, Warszawa 2002/2003; J. Widacki, Wywiad litewski w latach trzydziestych XX wieku jako przeciwnik wywiadu Korpusu Ochrony Pogranicza, ,Wojskowy Przegląd Historyczny' 1995, No 3-4, pp. 85-94.

9 For a list of 302 agents detained in Lithuania in the period 1921-1939, see: A. Anušauskas, Lietuvos slaptosios tarnybos (1918-1940), Vilnius 1993, pp. 326-329. 
cret services enabled them to conduct effective operational actions, and to exert counter-intelligence-based control over the area of the state, and also to monitor closely the Polish minority. Despite these difficulties, the Intelligence Agency of the 6th Brigade of KOP worked very efficiently, sending weekly reports and quarterly information notes with information on the Lithuanian border police, on the deployment of armed forces, their arms and equipment, the development and modernisation of military facilities, significant events occurring around the border, on the organisation, composition, armament and equipment of the Lithuanian Riflemen's Union (Šauliai), and on training agendas and the proceedings of exercises. For example, in 1935, the training agenda was intercepted, elaborated by Lieutenant-Colonel Jonas Kazitenas-Kaziutis, acting commandant of the Riflemen's Union. ${ }^{10}$

The information acquired by the KOP intelligence agency and by posts of the Civil Police was very valuable, albeit fragmentary. That is why officers of Polish intelligence tried to penetrate the command structure of the Lithuanian army to look for secret documents. The aim was achieved several times: for example, orders issued by the Ministry of National Defence (Krašto Apsaugos Ministerija) in 1922 were intercepted. On their basis, one could reconstruct precisely personnel changes in the entire Lithuanian army. Many organisational and personal commands issued by the 2nd Infantry Division in 1923 were also obtained, among which were commands issued by the regiments making up the division. ${ }^{11}$ On the other hand, in 1924, one managed to make copies of the 3rd and 5th regiments of the infantry. ${ }^{12}$

What was also methodically analysed were Lithuania's national and local press and thematic publications (such as books, brochures and textbooks). Information acquired occasionally from accidental, and mainly unwitting, informers or civil refugees, smugglers or fugitives from the Lithuanian army crossing the Polish border, was also much used.

Polish intelligence was interested in virtually everything that pertained to Lithuanian affairs. That is why what was obtained was truly motley material: all sorts of reports (many notifications issued by agents), periodically drafted statements and notes pertaining to the politico-military, social and economic situation in Lithuania, current reports coupled with extended lists and data related

10 CAW, Oddział II Szt. Gen., I.303.4.5344, Program wyszkolenia rekruckiego i wyszkolenia szaulisa zatwierdzony przez płk. Szt. Gen. S. Raštikisa, szefa Sztabu Najwyższego 8 I 1935 r [The programme for training recruits and training of Šauliai approved of by Colonel of the General Staff S. Raštikis, the chief of the Supreme Staff].

11 P. Lossowski, Stosunki polsko-litewskie 1921-1939, Warszawa 1997, p. 203.

12 CAW, Oddz. II Szt. Gen., reference symbol of the documents I.303.4..1768. 
to the Lithuanian army (ordres de bataille), border police, security service police and even criminal police, with the data being prepared on the fly. ${ }^{13}$

The collected data was then forwarded to the Office of Records and Studies of the Second Department of the General Staff, where it was merged, analysed and elaborated. Secret information notes and completed (updated) ordres de bataille of the Lithuanian army were drafted on their basis. ${ }^{14}$ Each information note was divided into several sections: the internal situation of Lithuania (which in turn encompassed the operations of political parties and social organisations, relations between the government and the opposition, the situation of national minorities, changes in personnel in the highest state authorities, administration and education), the international situation in Lithuania (including, in particular, relations with Germany, the USSR, the Baltic States, Czechoslovakia and the League of Nations), and the economic and military condition of Lithuania.

From time to time, officers of the Second Department prepared more extensive synthetic elaborations, to be distributed in the form of paperback brochures. Their purpose was to forward, first and foremost to the officer corps of the Polish army, information about the overall structure of Lithuanian military relations, and the most important political and economic affairs in the country.

The first such brochure came out in March 1925, and bore the title Wojsko litewskie (The Lithuanian Army). ${ }^{15}$ Its authors wrote that the brochure was a result of the information amassed up to the autumn of 1924, and simultaneously issued a disclaimer that the information may diverge from the actual state of affairs. That is why they declared that events in Lithuania would still be closely watched and subject to investigation by the General Staff, and the results would be further issues of the brochure, with forthcoming issues expected to be possibly corrected and expanded. ${ }^{16}$ There were two appendices attached to the main body of the text of this information brochure, a map of Lithuania with the deployment of military units and of platoons of Šauliai marked. ${ }^{17}$ In 1934, the Second Department of the General Staff of the Polish army presented the next study, called Polożenie polityczne, gospodarcze i wojskowe Litwy (The Political, Economic and Military Situation of Lithuania). ${ }^{18}$

13 See, for example: Centralne Archiwum Wojskowe w Warszawie (CAW), Oddział II Sztabu Generalnego (Szt. Gen.), I.303.4.5344, Meldunek wywiadowczy nr [Intelligence report no] 1/36, załącznik nr [appendix no.] 23 of 30 IV $1936 \mathrm{r}$.

${ }^{14}$ See, for example: CAW, Oddz. II Szt. Gen., sygn. [reference symbols of the documents] I.303.4.1788; I.303.4.1851; I.303.4.5161; I.303.4.5163.

15 Wojsko litewskie. Opracował Oddział II Sztabu Generalnego, Warszawa 1925.

16 Ibidem, p. 1.

17 Ibidem.

18 Russian State Military Archive (Российский Государственный Военный Архив - RGWA), Storage Centre of History and Documentary Collections in Moscow (Центр Хранения 
In 1935, the Third Department (Instructional-Operational) of the General Staff in operational and strategic studies made an effort to specify potential actions by Lithuania in case of war. After an analysis of the political and military contingencies, it came to the conclusion that: 'The possibility of Lithuania standing up alone to Poland is completely improbable. It is feasible only given our conflict with USSR or with the Germans. Lithuania would join a war only if there were any marked successes in military operations. ${ }^{19}$

Just in case, more narrow, selected problems were synthetically elaborated. For instance, in the period 1927 to 1928, there appeared reports and studies of branches No 1 in Vilnius and No 2 in Warsaw, as well as of the post 'Nord' pertaining to Polish-Lithuanian relations between 1920 and 1928, the ordre de bataille of the Lithuanian armed forces, Lithuanian-Soviet cooperation, the upheavals in Lithuania in December 1926, the activities of the Lithuanian minority, and German intelligence in Lithuania. ${ }^{20}$

Many important bits of information were provided by the Polish intelligence post in Wolne Miasta Gdańsk (the Free City of Danzig, WMG), which launched its operations at the turn of February and March in 1920. First, it bore the cryptonym Biuro Wywiadowcze w Gdańsku (Intelligence Bureau in Gdańsk, BWG), and then became Branch No 2 of the Second Department of the General Staff of the Polish Army (the only such post located outside Polish state borders). ${ }^{21}$ For ten years, it was a focal point of Polish military intelligence oriented towards northeast Germany and WMG. Its task was to observe German East Prussia and the Duchy of Pomerania, and the area of WMG. Due to the idiosyncratic situation of WMG, keeping an eye on German contacts with Soviet Russia and Lithuania was one of the tasks of the intelligence post in Gdańsk.

In 1925, it was renamed Branch No 7, and then started to use the expressions BIG (Biuro Informacyine w Gdańsku, Information Bureau in Danzig) and Referat Informacyjny Wydziału Wojskowego Komisariatu Generalnego Rzeczypospolitej w Gdańsku (KGRPG, Military Department Information Section of the General Headquarters of the Republic in Gdansk). ${ }^{22}$ The renaming was not only a formal move, it was also substantive. After all, from that moment, the

Историко-Документальных Коллекции - CPH-DK) in Moscow, f. 308, op. 3., t . 295, Położenie polityczne, gospodarcze i wojskowe Litwy [Political, economic and military situation of Lithuania]. Elaborated by. Oddz. II Sztabu Głównego. 1934 r.

19 RGWA-CPH-DK, f. 473, op. 1., t 98, Możliwości i warunki wojny [Possibilities and Conditions of War]. Oprac. Oddz. III Sztabu Głównego. 1935 r., p. 13.

${ }^{20}$ CAW, Oddział II Szt. Gen., sygn. I.303.4.1792.

21 For more on this issue, see: W. Skóra, Pierwsze lata działalności polskiego wywiadu wojskowego w Wolnym Mieście Gdańsku (1920-1925), ‘Zapiski Historyczne’ 2005, vol. 1, pp. 55-65.

22 Skóra Wojciech, Działalność gdańskiej ekspozytury polskiego wywiadu wojskowego w latach 1920-1930 (Pomorze Zachodnie, Prusy Wschodnie i Wolne Miasto Gdańsk), Poznań 2011, 
post in Danzig concentrated its efforts on reconnaissance of the terrain of Wehrkreis I (Kaliningrad) and of Wehrkreis II (Szczecin), that is, East Prussia and the Duchy of Pomerania, respectively. However, this was only a supplementary task: it amounted to a mere complement of the work conducted by Branch No 2 in Warsaw and Branch No 3 in Poznań. ${ }^{23}$

The area of the Free City of Danzig was particularly favourable for conducting intelligence-related operations. This was not only due to its geographical location, or transport-related considerations (a large sea and inland port, an important railway and road junction) and the ease of travelling to WMG, but also due to legislation in Gdańsk which did not provide for punitive sanctions for espionage. For that reason, in the WGM area, great operativeness was exhibited not only by Polish and German intelligence, but also by other special services: Soviet, Lithuanian, British and even nationalist Ukrainian organisations, and the secret services of Russian emigrés. ${ }^{24}$

The most important intelligence post of the branch in Gdańsk in the 1920s involved in the reconnaissance of Lithuania was the officers' post in Kaliningrad. It was Post No 1 operating in the period 1922 to 1926, and bearing the cryptonym 'Roman', ${ }^{25}$ first run by Mieczysław Pogorzelski, and subsequently by Lieutenant Marian Skorupa. In the period 1926 to 1928, its cryptonym was renamed from 'Roman' to 'O.6', and subsequently to (interchangeably) 'Ribbentrop', 'Riebentropp', 'Z.2', with the post being run by Marian Skorupa, who was promoted to captain. ${ }^{26}$

In the post 'Roman' in Kaliningrad, a study (the author or co-author of which was Lieutenant Skorupa) was released which presented the organisation, tasks and methods of the functioning of Lithuanian intelligence oriented towards Poland in a synthetic manner:

The main attention of Lithuanian political and military intelligence is directed, first and foremost, against Poland. What is of secondary interest is the observation of German areas.

The military intelligence aims mainly at unearthing Polish mobilisation plans, which were allegedly elaborated in numerous variants. What was scheduled as a subsequent task for Lithuanian intelligence was the following: unearthing secret

p. 57-58; A. Szymanowicz Adam, Na tajnym froncie polsko-niemieckim. Polski wywiad w Prusach Wschodnich 1918-1939, Gdynia 2013, pp. 160-161.

${ }^{23}$ Skóra Wojciech, Działalność gdańskiej ekspozytury polskiego wywiadu wojskowego..., p. 58.

24 Ibidem, s. 20.

25 For this post, three agents provided their services, whose monthly salary amounted to 70 USD.

Ibidem, p. 59.

${ }^{26}$ Ibidem, p. 77. 
commands pertaining to the organisation of the Polish army, its armament, making fortification plans in the Vilnius belt, and the observation of Polish ammunition stocks in Gdańsk.

With reference to this last issue, the intelligence agency of the General Staff in Kaunas has recently sent special intelligence officers to Gdańsk and Gdynia for a permanent sojourn, whose exclusive task is to keep an eye on unloading military transport in these ports. The names of these intelligence officers are yet unknown; however, the fact is that they are equipped, just like many others, with Lithuanian passports.

With respect to the intelligence service oriented at Germany, Lithuanian intelligence, due to the necessity of sustaining friendly relations with the Germans, conducts these operations very cautiously, and confines itself mainly to unearthing information pertaining to new inventions introduced in the Reichswehr, and to acquiring information on the condition and development of the army of rightwing organisations in East Prussia, and on the contacts of these organisations with various staff of the Reichswehr.

The head of the intelligence office of the Lithuanian General Staff is Major Užupis, ${ }^{27}$ a man of average intelligence. A section of Polish intelligence is run by Major Jaksztas, ${ }^{28}$ the German one by Lieutenant Krantas. ${ }^{29}$

Lithuanian intelligence directed at Poland cooperates closely with the corresponding German intelligence, and in this respect there is an ongoing exchange of material of interest to both of these parties. Lithuanian intelligence bodies willingly enable German intelligence officers to cross the former's border on their way towards Poland more easily. Contact with the Germans in Kaunas was kept mainly by Captain Klein, ${ }^{30}$ who remains an official of the German deputation. One of the most active intelligence officers under Captain Klein is Woroboras, a Ukrainian, who often crosses the green border heading for Vilnius.

27 Antanas Užupis.

28 Antanas Jakštas.

29 In fact, there was no officer with this name in the Lithuanian officer corps.

30 Captain Joachim Klein ran a German intelligence post in Kaunas (cryptonym Likogu), which reported to the Asto (Abwehr-Stabs-Offizier) office operating at the staff of the First Division of Reichswehr, and simultaneously at the First Wehrkreiskommando in Kaliningrad. The Asto office in Kaliningrad was run by Captain Denecke in the mid-1920s. See: A. Szymanowicz, Na tajnym froncie polsko-niemieckim. Polski wywiad w Prusach Wschodnich 1918-1939, Gdynia 2013, p. 63. Captain Klein was also most likely a messenger for the Asto office from Kaliningrad at the Lithuanian General Staff. See: J. Budrys, Kontržvalgyba Lietuvoje, New York 1967, p. 147; H. Kopczyk, Niemiecka działalność wywiadowcza na Pomorzu 1920-1933, Gdańsk 1970, pp. 146-147; W. Kozaczuk, Bitwa o tajemnice. Służby wywiadowcze Polski i Rzeszy Niemieckiej 1922-1939, Warszawa 1977, p. 157; A. Anušauskas, Lietuvos slaptosios tarnybos..., pp. 179-182, 189, 193. 
In Klaipeda, contact with German intelligenceiskept bythe Lithuanianagent Josef Lemberg, originating from Kybartai. He collaborates with the following Germans: Frischmann, managing the Meyhoefer company in Klaipeda, Karl Jossesom, a bank clerk, Draeger, a clerical worker with the Memeler Bank, and Arendt, the owner of the tobacco company Krueger Oberbeck, Klaipeda. The residences of the above-mentioned companies serve as venues for German agents.

The Lithuanian political police directs its secret service operations at Poland similarly intensely. ${ }^{31}$ The head of this police is Racys, ${ }^{32}$ being directly subordinate to the Department of Public Security, which is in turn headed by Jakobas. ${ }^{33}$ The central headquarters of the political police is located in Kaunas, and is divided into seven sections. In the political police bureau, apart from the heads of particular sections, 29 officials are employed, including the head of the chancellery Neuortas.

Kowno [Kaunas] in Lithuania is divided in terms of police-political administration into six circles, that is, so-called points. They are situated in Sauiai, ${ }^{34}$ Ponewez, ${ }^{35}$ Mazeikini, ${ }^{36}$ Uktegde, ${ }^{37}$ Alita, ${ }^{38}$ Wilkowyski ${ }^{39}$ and a separate point in Klaipeda (Valstibynas ${ }^{40}$ Policijos Skyriaus). The head of the political police in Klaipeda is Jonas Kazlauskas, whereas his assistant is Koceman.

Particular sub-units are subordinate to heads of districts. The former are scattered in a network all across Lithuania. In border districts, the network is more and more dense. Separate agents scattered all around the whole province are subordinate to individual sub-districts. The entity collaborating tightly with the political police is the Riflemen's Union, whose members act as informers for the police.

The head of the point of the political police in Klaipeda is Kazlauskas, who operates very actively, combating German right-wing organisations, Polish intelligence, the agents of which are allegedly flooding into Klaipeda, and with the operations of communists reputedly originating out of Tilžè.

The most active of Kazlauskas' agents are:

31 Była to Policja Polityczna (politinè policija).

32 Antanas Račys.

33 A. Jakobas.

34 Šiauliai.

35 Panevėžys.

36 Mažeikiai.

37 Ukmergé.

38 Alytus.

39 Vilkaviškis.

${ }^{40}$ Valstybès. 
Wasilkowski, a former Russian officer. ${ }^{41}$ The deconspiration of the Polish intelligence agent Galin and his cohort is attributable to his provocation. ${ }^{42}$ Wasilkowski has many acquaintances in Klaipeda, and contributes vital services to the Lithuanians.

The merchant Raszawitz uncovered the French intelligence agent and former Russian officer Sizich, ${ }^{43}$ as well as Kupler, a German intelligence agent.

The owner of a newsagent's, Mering, running secret service operations among German right-wing organisations. He is often to be found at Kruger's cigarette warehouse, where briefings for Kazlauskas' agents take place.

Among the counter-intelligence agents of the political police, persons also worth mentioning include: Nudzielis, Sestakauskas, Geronis, Rudkauskas, Celkas and Kochas Jurgis.

In a Klaipeda post office, there is the so-called black office, the task of which is to monitor incoming mail.

${ }^{41}$ Dymitr Wasilkowski, the son of Count Aleksander Koszuro-Wasilkowskiego, was an officer in the Imperial Russian army who joined the Lithuanian army. He served in the second platoon of an auto-battalion, which in January 1926 was transformed into an auto-company.

42 Włodzimierz Galin, a former Imperial Russian officer, was recruited for Polish intelligence by the cavalry captain Karol Dubicz-Penther, the head of the Intelligence Post in WMG. At the beginning of the 1920s, he succeeded in establishing an intelligence network in which officers of the Lithuanian army and members of the Lithuanian Riflemen's Union were to be found. Thus, in the mid-1920s, Polish intelligence acquired a deep insight into the condition of the Lithuanian armed forces. In the information gathered by Galin's network, many pieces therefore pertained to Lithuanian and Belarusian guerrilla operations in the area of the republic adjacent to Lithuania (in the Vilnius, Novogród and Suwałki regions), organised and financially and logistically supported by the authorities in Kaunas. The information was also related to the political, social and economic situation of Lithuania. Authorised by the chief of the Branch of the Second Department in Vilnius, Galin contacted and started negotiations with Wiaczesław Chmara-Razumowicz, one of the four commanders of insurgent groups under the Belarusian General Staff. This staff coordinated sabotage-related and subversive activities in Poland commissioned by the Lithuanian General Staff. It is still unknown by what means Wasilkowski managed to get in touch with Galin (perhaps one factor facilitating it was their common past in the Russian army). However, the effect of this acquaintance was to identify Galin's intelligence network and arrest its members in August 1924 (see: T. Gajownik, Tajny front niewypowiedzianej wojny. Działalność polskiego wywiadu wojskowego na Litwie w latach 1921-1939, Warszawa 2010, pp. 117-118). A. Anušauskas contends that whoever contributed to disclosing the intelligence-related operations of Galin was Captain Klein's agent Wagner (his real name was Breitgam), who in turn simultaneously worked as a secret service agent for the Lithuanian political police (see: Lietuvos slaptosios tarnybos..., p. 181). The possibility cannot be ruled out that he was actually Walter Bräutigam (nicknamed Władysław Brusow), a bureaucrat in the Lithuanian political police in Klaipeda. Galin and the members of his intelligence network were imprisoned in Kaunas. At his trial, Galing was sentenced to death, and the execution was carried out at the end of 1924. The same fate most likely befell three other agents of Polish intelligence in his network.

43 Władimir Iwanowicz Sizych (Vladymiras Sizichas); for more on his intelligence-related activities, see: T. Gajownik, op. cit., pp. 131, 167-170, 178-180, 233-254. 
The heads of the political police, like the heads of offensive intelligence, collaborate with one another in identifying Polish intelligence officers together with German activists inhabiting Lithuania, that is, with, among others, Chamier, Broedrich, Baumgaertl and Kelin, who often in their respective private letters underline both the ineptitude of the Lithuanian political police and the necessity of giving direct information to the police on existing hostile intelligence organisations. ${ }^{44}$

The characteristics of Lithuanian intelligence drafted by the Polish post in Kaliningrad corresponded with the reality to a large extent. After all, the tasks set for it, as well as the possibilities of performing them, were a derivative of Lithuanian military doctrine on one hand, and of quite scanty personnel and financial resources on the other. Kaunas realised the weaknesses of the fighting and military potential, and that is why the plans elaborated were of a defensive nature: the plan for a war with Poland (Plan 'L', standing for Lenkija), the plan for a war with the Germans (Plan 'V', standing for Vokietija), and the plan for war with both Poland and Germany (Plan ' $\mathrm{L}+\mathrm{V}$ ', standing for Lenkija and Vokietija). The main task of returning Vilnius (the Vilnius region) to Lithuania could only be successfully performed under favourable international conditions; that is, in the event of an armed conflict by the Republic with Soviet Russia or the Germans. These two states, for most of the interwar period, were perceived by the politicalmilitary administration of Lithuania as allies, proving to be of some assistance in realising the ultimate goal, regaining Vilnius from Poland.

Right up until the end of the 1930s, Poland was considered in Kaunas as the enemy number one. For that reason, in order to understand the Polish war potential and its operational plans, Lithuanian intelligence cooperated both with Soviet and German intelligence.

Cooperation with Soviet intelligence was pretty close, which is evinced by the fact that Lithuanian intelligence shared with the Soviet one its own network of agents (especially border smugglers) and the steps the former took in the area of Poland. What was also shared with Soviet intelligence was information acquired pertaining to Poland, with the information lying outside the area of interest of Lithuanian intelligence. An intermediary between Lithuanian and Soviet intelligence was the Soviet military attaché in Kaunas. ${ }^{45}$

${ }^{44}$ CAW, Oddział II Szt. Gen., sygn. I.303.4.7792, the report issued by 'Roman’ post, 1925 r.

${ }^{45}$ J. Widacki, op. cit., p. 87. 
Cooperation between Lithuanian intelligence and the German Abwehr, in their actions directed against Poland, commenced in the early 1920s, and involved sending to Poland citizens of Lithuania acting as intelligence agents, gathering information which was not only useful to Lithuanian intelligence but also of some interest to the Germans. ${ }^{46}$ This changed only at the turn of the 1930s, when after the dissolution of independent Czechoslovakia, the administration of the Third Reich came to the conclusion that the time had come to raise the issue of Klaipeda (the Klaipeda region). It was only then that in Kaunas they realised that the Third Reich posed a real threat to Lithuania's territorial integrity.

The assumption for most of the interwar period that the most probable conflict would be an armed conflict with Poland, ensured that the main effort by Lithuanian intelligence was towards collecting information from areas bordering Lithuania: the Vilnius and Białystok districts. From a military point of view, it was the area of the Corps District Command (DOK) No 3 in Grodno (Gardinas): the largest garrisons were situated in Nowa Wilejka, Postawy (in Lithuanian Pastovys), Vilnius, Grodno, Augustów, Suwałki, Białystok, Grajewo, Vawkavysk (Valkaviskas), Lida (Lyda) and Mołodeczno (Maladzyechna). From 1924, the Polish-Lithuanian border was guarded by battalions and squadrons of the KOP 6th Brigade, and then of the Wilno (Vilnius) and (Grodno) KOP brigades.

Apart from purely intelligence-related tasks, the second most important one was to take counter-intelligence offensive actions; that is, discovering, working out and hindering (or even liquidating, if possible) the operations of the Polish secret services.

To effectively realise both these goals, Lithuanian intelligence kept recruiting informers among Lithuanians living in Poland, as well as among Poles residing in Lithuania, if not permanently then at least temporarily. The people recruited for intelligence-related work were preferably those most nationalistically inclined, and at the same time exhibiting desirable psycho-physical traits. ${ }^{47}$

From the early 1920s, Lithuanian intelligence boasted a fixed network of intelligence agents-residents, who were people who officially had permanent residence in Poland. Their task was to collect information from informers, and then to forward it to the central headquarters of Lithuanian intelligence, which was first the Intelligence Department (Žvalgybos Skyrius) of the General Staff, and later the First Information Department of the Supreme Staff (Informacijų Skyrius Vyriausiasis Štabas). ${ }^{48}$ Informers were divided into permanent and temporary ones, with the latter forwarding information only once. There were unpaid

\footnotetext{
46 Ibidem.

47 Ibidem, p. 89.

48 A. Anušauskas, Lietuvos slaptosios tarnybos..., pp. 114-115.
} 
informers working for Lithuanian intelligence without reward, as well as paid informers. Intelligence functionaries who illegally stayed in Poland in order to perform a specific task counted as agents. An important role was played by carriers, who kept in touch with residents and receivers of information in Lithuania. In the majority of cases, they had to cross the border illegally.

Information was normally gathered via simple methods, such as the observation of a targeted object, contact and conversations with persons at a given time on duty, or simply working in military, paramilitary organisations, the civil police and railway and state or local administration. What took considerably higher qualifications and skills was the realisation of goals pertinent to offensive counter-intelligence. After all, what was sought was access to Polish border intelligence and counter-intelligence posts, with the posts of interest conducting subversive and intelligence and propaganda-related operations in Lithuania.

A serious threat to Polish intelligence was posed by Lithuanian female intelligence agents. They delivered the most painful blows. The first female agents were hired for the secret services in the autumn of 1918. Liudas Gira, who was commissioned to create a Lithuanian military information service, designated about 20 women for this sort of work. He came to believe that 'they were in a privileged position to learn all the rumours in the city [...] and on top of that, they seemed to be the greatest idealists, who could really work reliably and without any reward, but only for an idea .... ${ }^{49}$

Among them was Marcele Kubiliūte (1898-1963), ${ }^{50}$ who was sent to Vilnius in 1919 with the task of acquiring information on the Polish garrison and military transport crossing the railway junction, and of collecting Polish military publications, etc. Under the pseudonym Elza, she became a resident of Lithuanian intelligence in the city, and built up an efficient intelligence network. The documents she collected were then transferred to Kaunas by the messenger Ona Mikalauskaite. The actions of Kubiliūte were guided by Lieutenant Juozas Matusaitis of the Intelligence Department (Žvalgybos skyrius) of the Lithuanian General Staff. ${ }^{51}$ Officially, Kubiliūte was a shipping clerk, and editor of periodicals (in the Lithuanian language) issued in Vilnius: the newspaper Nepriklausoma Lietuva (Independent Lithuania), and the weekly Vilnius Garsas (The Voice of Vilnius). She also kept in touch with the editorial board of 'The Voice of Vilnius' issued from 15 May 1919 in Polish. This high-quality daily, edited by Mykolas Biržiška, was supposed to reach an audience of polonised Lithuanians, and to inform Poles residing in Vilnius on the position of the Lithuanian side with

49 Ibidem, p. 10.

50 Biographical note, see: A. Anušauskas, Lietuvos žvalgyba 1918-1940, Vilnius 2014, pp. $32-33$.

51 Ibidem, p. 32. 
respect to the state affiliation of the Vilnius region. In practice, the daily was very unfavourably biased against Polish activities. The director of 'The Voice of Vilnius' was Aldona Čarnackaite (born 1898), who started her cooperation with intelligence in 1918, when she returned to Lithuania from St Petersburg where she had studied medicine. She lent a helping hand in organising the Lithuanian army; she was secretary to Jonas Basanavičus, the leading activist in the Lithuanian national movement. After the Lithuanian authorities evacuated Vilnius at the end of 1918, she remained in the city and became a confidential assistant of Biržiška.

As editors of periodicals in Vilnius, both women had frequent contact with the censorship section of the Vilnius press of the Branch of the Second Department of the Supreme Command of the Polish Army, then commanded by Captain Marian Kościałkowski. One of the functionaries in the Vilnius branch was Piotr Wróblewski. Since he was trusted by Captain Kościołkowski, he had access to the most secret documents. We do not know exactly when and under what circumstances Wróblewski started his cooperation with Lithuanian intelligence. However, all the evidence points to the hypothesis that it happened due to the influence of Aldona Čarnackaite in the summer of 1919. That was when the Kaunas district of the Polish Military Organisation (also referred to as POW) headed by Lieutenant Rajmund Kawalec, subordinate to the Branch of the Second Department in Vilnius, was concluding preparations for the uprising in Kowno (Kaunas) in Lithuania, which was supposed to overthrow the government, hostile to Poland, of Mykolas Sleževičius, and to dissolve the Council of Lithuania (Lietuvos Taryba). Wróblewski was well aware of these plans. Nowadays, it is rather difficult to reconstruct the reasons for his actions. Regardless of whether he was driven by material issues, emotional involvement, or an option which cannot be dismissed out of hand, both at the same time, he bragged in the presence of Čarnackaite that he was a trusted agent of Captain Kościałkowski, and it was on the latter's command that he travelled to Kaunas with special tasks to perform. He maintained that he was aware of Polish military plans for Lithuania, and for a due reward he could forward these plans to the prime minister Sleževičius. Information on his offer reached Kubiliūte, and she in turn, via the carrier Ona Mikolauskaite, forwarded this information to Kaunas. The Lithuanians accepted the offer, gave Wróblewski the pseudonym Daukantas (Dowkont), and asked for details. Then Wróblewski forwarded to them the news that on 28 August an armed attack by the POW was going to take place, endorsed by the members of the Organizacja Strzelców Nadniemeńskich (Nemunas Riflemen's Organisation, OSN). Shortly afterwards, a list of 66 members of the OSN, collected by him from an archive of the Vilnius district of the POW, was captured 
by the Lithuanians. Arrests started at night on 28 August, on a command issued by Liudas Gira, the head of the Intelligence Department. About 200 people were detained, including 15 officers. There was no conclusive evidence that they were preparing an uprising. Jurgis Bobelis, one of the officers at the Kaunas headquarters who took part in the liquidation of the conspiracy, wrote: 'We received the information that somewhere in Kaunas there was a whole archive of POW, after the discovery of which everything would be clarified. For some time, we were groping around blindly. We got the information that the archive was stored at Raudondvaris. We travelled there, searched through all the corners, and, having found nothing, came back. ${ }^{52}$

In all likelihood, they would not have discovered that archive had 'Daukantas' not lent a helping hand yet again. Realising that at each moment he could get unmasked, on 21 September 1919, Wróblewski took from the files of the branch the next important documents and handed them to Čarnackaitė. From Čarnackaite, the documents reached Biržiška, who in turn arranged for them to be transported to Kaunas.

It was there that Wróblewski fled. Afterwards, he informed the Lithuanians that the archive of the POW was in Kaunas in the house of Niekraszowie, at 36 Podgórna Street. A department of the headquarters immediately went there, and after a search of many hours, after raking through the garden, they found the documents hidden in a tin kettle. Since they also found a code, what was read off were the names of 369 POW-related individuals, and of 122 Lithuanians who were sympathetic to them. Arrests were made immediately. Among others, the people detained included Kawalec and Stanisław Niekrasz, the chief of the Intelligence Department of the POW.

Aldona Čarnackaite also had to flee from Vilnius. She went to Kaunas, and several months later, in 1920, she was sent to Berlin to study medicine. She graduated in 1924. For her contribution in the war of independence, and, more specifically, for her contribution to the liquidation of the Polish conspiracy in the Kaunas region, in 1928 she was awarded the most distinguished Lithuanian decoration, the Order of the Cross of Vytis (Vyčio Kryžius).

The role played by Kubiliūte, a Lithuanian intelligence resident of Vilnius, was not revealed in the Wrólbewski affair. Therefore, for almost three more years she was able to run espionage operations with impunity, which she described as follows: 'While working in Lithuanian intelligence, I took advantage of the Polish Major Antoni Jankowski's advances. ${ }^{53} \mathrm{He}$ occupies a certain rank in the military staff, so is of interest to the Lithuanian Department of the General Staff. Per-

52 P. Łossowski, Konflikt polsko-litewski 1918-1920, Warszawa 1996, p. 73.

53 There was no Major Antoni Jankowski in the Polish army in the early 1920s. See: Rocznik oficerski [Officer Yearbook] 1923, Warszawa 1923. 
forming the tasks imposed by these departments, I remained for a long time in an intimate relationship with Major Jankowski, and at the same time I obtained from him information of interest to Lithuanian intelligence and pertaining to the Polish army. ${ }^{54}$ The secret-service nature of Kubiliūte's operations was revealed only in 1922. However, she managed to flee from Vilnius by using fake identity documents bearing the fictitious name of Elżbieta Boniewicz. In Lithuania, she was employed in the Ministry of Foreign Affairs. For her contribution in the war of independence, she was also awarded the Order of the Cross of Vytis in 1928.

It is said that historia magistra vitae. However, sadly, this insightful dictum of Cicero's is often forgotten. It seems that the events of 1919 and the period 1920 to 1921 should have stuck in the memories of members of the Second Department. However, that was not the case. Six years later, another huge intelligencerelated scandal took place. This time, the main role was played by Lieutenant Ryszard Grzybowski, the head of the Counter-Intelligence Office of Branch No 1 of the Second Department in Vilnius.

The intelligence-related scandal was initiated in 1924, when the Information Department (Informaciju skyrius) of the Lithuanian General Staff received the information that in Vilnius, one of the members of Polish intelligence was having a vibrant social life. He was seen in the best restaurants almost on a daily basis, often in the company of women. The Lithuanians decided to take advantage of this. Shortly afterwards, in cafés and restaurants in Vilnius, or in the places most frequently visited by the Polish officer, a young, attractive and elegant woman started to appear. Lieutenant Grzybowski immediately turned his attentions to her, and in consequence found the opportunity to get to know her personally. They started to meet more and more frequently, and the restaurant and café bills were paid for by the girl of 'Mr Lieutenant'. All this resulted in a stormy love affair. Soon, violating the work code binding him, Lieutenant Grzybowski started to invite her to his office in the branch in Vilnius. In April 1925, at another thrilling meeting, the Lithuanian agent poured a soporific into his glass. After waking up, Lieutenant Grzybowski noticed that his lover was gone. But he was consumed with fear only when he noticed the absence of the personal files of Polish agents oriented towards Lithuanian affairs. The reckless officer could be tried, and a military court could demand the ultimate punishment, death by firing squad. In this situation, the lieutenant decided that the best solution was to flee to Lithuania. That was what he did. Once there, he forwarded to officers of the Lithuanian Informaciju skyrius all the information he had on the working methods of Polish intelligence in Lithuania; he also informed on all the agents and informers known to him. This in turn allowed Lithuanian counter-intel-

54 A. Anušauskas, Lietuvos žvalgyba..., p. 105. 
ligence to liquidate many Polish intelligence posts, and to arrest many agents. The first information on Lieutenant Grzybowski's escape to Lithuania and on his forwarding secret documents and statements reached Polish intelligence after only a few days. Therefore, he did not have time to warn his agents. The one who survived had to flee from Lithuania. This was one of the biggest and most painful defeats of prewar Polish military intelligence.

The restoration of intelligence structures required time. This task was taken up by Branch No 1 in Vilnius, while taking advantage of the assistance given by the post 'Nord' in Riga. This post boasted a wide array of possibilities for action, since the second intelligence post of the Second Department 'Wiera' operating in Latvia was subordinate to its head. The post was headed by Lieutenant-Colonel Vladimiras Sizychas, who in the period 1919 to 1920 created the Lithuanian secret services, intelligence and counter-intelligence. ${ }^{55}$ Acquaintances and contacts Sizychas had among his former colleagues resulted in supplying Polish intelligence with valuable information originating from two major Lithuanian institutions: from the Ministry of Internal Affairs and from the Supreme Staff.

In the middle of 1926, in Lithuania, there were already eight mobile agents and intelligence posts, two of them, 'Krysia' and 'Marta', were in Kaunas, whereas the third one, an emergency post situated on the border, was supposed to take appropriate action under extraordinary circumstances, such as the mobilisation of the Lithuanian armed forces, the concentration of troops, or a military coup d'état, etc.

In 1926, the interests of Polish military intelligence were centred around several issues. The first, and at the same time the most significant, was to observe the changes occurring in the Lithuanian armed forces, state security bodies, and the Lithuanian Riflemen's Union (Lietuvos Šaulių Sąunga). What aroused special interest was the reduction of the armed forces carried out in Lithuania, with the reduction purportedly amounting to, according to the reports received, a third of overall resources.

In the second half of 1926, the focal point of Polish intelligence was the reorganisation of the army introduced by Mykolas Sleževičius' government. What was recorded and analysed then were all the programme declarations, as well as the public speeches made by the prime minister and the minister of national defence relating to the army. The new chief of the Supreme Staff, LieutenantColonel Kazys Škirpa of the General Staff, also aroused considerable interest.

The intelligence agency of the KOP stated that the minister of national defence, Lieutenant-Colonel Juozas Papečkys, based the reorganisation on the principle of

${ }^{55}$ For more on this issue, see: Ibidem, pp. 19, 22, 24-26. 
'staffsfor lines, and not troops ofaline, asa supplement forstaffs'.${ }^{56}$ They also recorded personnel-related and organisational changes, as well as observing what was happening in military circles, in linear units and in military services. After having analysed the whole programme, and having compared the budget of the Ministry of National Defence from 1926 to the prospective budget planned for 1927, Polish analysts, however, came to the conclusion that '.. the reorganisation of the Lithuanian army involves only an apparent reduction, because in place of departments and offices closed down, new ones have emerged. ${ }^{57}$

From the spring of 1926, the internal political situation of Lithuania became an object of increased attention by the agencies of the Second Department of the General Staff of the Polish army and of the KOP Intelligence Agency. All this was connected with the forthcoming elections. The actions carried out were aimed at the most thorough penetration of Lithuanian political parties and social organisations, as well as circles which served as their main support. The electoral campaign was also closely watched. The Intelligence Agency of KOP stated that: 'The ruling party, by all possible means, aimed at keeping power in their hands. To this end, the political police received an order to prepare fake left-wing electoral lists in order to sabotage elections. Heads of powiats, following instructions issued in Kaunas, prohibited the organisation of mass meetings; and even when one managed to obtain such a permission, the Christian Democrats dispatched envoys armed with sticks and clubs in order to prevent the insidious workings of the ruling party from being revealed. ${ }^{58}$

The Vilnius Branch of the Second Department, in its assessment of 19 May of the state of affairs in Lithuania, stated that: 'The ruling party, the Christian Democrats, was not helped by the votes of the military, with the military voting, pursuant to the order issued by the minister of the MOK [Ministry of State Security], on a par with other citizens. ${ }^{59}$ And the branch prophetically added: 'The ruling party would be ready even to carry out a coup d'etat. That grounds are made for the above possibility is evinced by the fact that troops from various garrisons are drawn to Kaunas under the pretext of participating in a national holiday on the 15th of the present month, which is a practice quite unknown in

56 CAW, Oddz. II Szt. Gen., sygn. I.303.4.2035, Komunikat informacyjny nr 3 za czas od 25 VII do 25 X 1926 r. [Information Notice no. 3 for the period between 25 VII to 25 X of 1926] Korpus Ochrony Pogranicza Dowództwo 6 Brygady [Border Protection Corps, the Command of the 6th Brigade]. Vilnius, 25 November 1926, p. 15.

57 Ibidem, p. 16.

${ }^{58}$ CAW, Oddz. II Szt. Gen., sygn. I.303.4.5281, Komunikat informacyiny nr 2 z dn. 25 VII 1926 r. Korpus Ochrony Pogranicza. Dowództwo 6 Brygady, p. 26.

${ }^{59}$ RGWA-CPH-DK, f. 460, op. 1, t. 107, Meldunek Ekspozytury nr 1 Oddz. II Szt. Gen. O położeniu na Litwie z 19 V 1926 r., k. 85-86 [Report Issued by Branch No 1 of the Second Department of the General Staff on the State of Affairs in Lithuania of 19 May 1926]. 
previous years, and which, given the financial predicament Lithuania is caught in, cannot be explained solely in ceremonial terms. ${ }^{60}$

The enhanced observation of the Lithuanian armed forces in May 1926 was also caused by Józef Piłsudski's military coup. The branch in Vilnius reported that: 'The events in Poland made the Lithuanian government anxious about the overall shape and integrity of its borders, and resulted in Lithuania issuing military and police orders. ${ }^{61}$ However, the branch rightly assessed that: 'The issues should not be perceived as encouraging militant actions, but rather as being of a defensive nature. ${ }^{62}$ And finally, it added: 'The Lithuanian government behaves with great moderation, and put off any offensive actions; by contrast, it strengthens the forces on its border and takes precautionary measures around it. Regardless of the normal strengthening of the border by $1 \mathrm{pp}$ (one infantry regiment), what was increased is the number of district border patrols on some stretches of land by $50 \%$ (this applies especially to the stretch of the VilniusTrotsky powiat. The behaviour of border patrols is anxious. The guards of the KOP report that the border areas are often illuminated by rockets. ${ }^{93}$

In the report that Branch No 1 sent to Warsaw on 19 May, it was stated that: 'The first news of the events happening in Poland, inaccurate, tendentious and grossly exaggerated with respect to material losses in Warsaw, was received in Kaunas only on the 14th of the current month, via Berlin and Riga. The Lithuanian press illuminates the events from Warsaw, while being favourably inclined towards Marshal Piłsudski; as a reason for the upheaval it cites the forlorn economic condition of Poland, after all the issues being raised for some time now. ${ }^{64}$

In 1926, Lithuanian intelligence hired another woman, Aleksandra Biedrzyńska, a Pole. She was a smuggler of saccharin, tobbaco and clothes. In 1926, she was stopped by a Lithuanian border patrol, which in turn informed intelligence officers of the event. Biedrzyńska was then taken to Kaunas, where she accepted the offer of the job of carrier, taking intelligence-related documents across the 'green' border. She was predisposed to this work since, having been smuggling for so many years, she had got to know the safest routes. She cooperated closely with Stanisław Żłobecki, who, after being released from the Polish army, decided to leave for Kaunas, hoping to get employed there. While illegally crossing the border, he was arrested by a Lithuanian border patrol and taken to Kaunas and put at the disposal of military intelligence. The hearing was con-

60 Ibidem, k. 87.

61 Ibidem, k. 85.

62 Ibidem.

63 Ibidem, k. 87.

64 RGWA-CPH-DK, f. 460, op. 1, t. 107, Meldunek Ekspozytury nr 1 Oddz. II Szt. Gen. O położeniu na Litwie z 19 V 1926 r., k. 85-86. 
ducted by Juozas Matusaitis, who suggested Żłobecki cooperate with Lithuanian intelligence. He was to return to Poland and settle in Vilnius. The offer was accepted. Żłobecki went to Vilnius, and took a job in Sztrall's Café, which enabled him to make the acquaintance of officers of the Vilnius garrison. He passed the information thus acquired on to Biedrzyńska. She, on the other hand, appeared throughout one year (from July 1926 to July 1927), bringing him financial rewards and intelligence-related instructions, and collecting from him the material he managed to obtain. It can be inferred from the statements she was later to make that the material in question was related to the deployment of forces, and to changes occurring there, as well as to military manoeuvres, the organisation of the Riflemen's Union, the deployment of units of the KOP, the arms carried by armoured troops, cavalry and artillery, and the structure of military facilities and roads. ${ }^{65}$ Whether at his own initiative or on the orders of his handlers in Kaunas, after some time, Żłobecki left for Warsaw, and took a job as a waiter in the Italia café, which was frequented by commissioned officers of the Polish army. On the basis of his observations, he was supposed to identify officers who, due to all sorts of addictions and professional as well as personal problems (of a financial or moral nature), could be susceptible to accepting an offer of cooperation. It can be inferred from the extant documents that Żłobecki was seen in the company of an officer of the Polish army, with both indulging in cocaine consumption at that time. The information obtained via these means was again transferred to Biedrzyńska, who kept coming to Warsaw to collect it. Kazimierz Szumski, a professional smuggler and also her lover, helped her cross the border. In return for the assistance in transferring intelligence-related materials, the Lithuanians tolerated her smuggling activities. On 20 February, Biedrzyńska was arrested and delivered to Polish counter-intelligence (officers of the Independent Information Office of Corps District Command No 1 in Warsaw). During the hearing, she informed on Żłobecki and Szumski, but only the former confirmed his cooperation with Lithuanian intelligence. ${ }^{66}$

From the early 1920s, Lithuanian agents-residents and agents-recruiters tried to get in touch with Lithuanians who were citizens of the Republic doing their mandatory military service in the Polish army. They were also interested in reservists, especially ones who had just completed their military service, or who had just come back from military exercises with the reserve force. Given the chance, they helped them illegally cross the border, and in Lithuania they interviewed them and questioned them in detail on issues which were of interest at

65 T. Gajownik, op. cit., p. 240

${ }^{66}$ Ibidem, pp. 240-241. 
any given time to Lithuanian special services. The people who helped reservists into Lithuania and then back to Poland were rewarded financially.

A counter-intelligence report by the Independent Information Office of Corps District Command No 3 in Grodno concerning the year 1933 noted that: 'As one of the distinctive features distinguishing the methods of Lithuanian intelligence from those employed by Soviet intelligence, what strikes us is the gross disparity with respect to their percentage shares of agents who were soldiers on actual duty. Whereas out of 86 agents of Soviet intelligence in 1933, none of them proved to be a soldier on actual duty, Lithuanian intelligence took advantage of the information provided by 7 (seven) privates on actual duty, that is, almost every fourth Lithuanian spy was a soldier on actual duty, a syndrome the remedy of which this Independent Information Office in 1934 will turn its special attention to. Another distinctive feature of the methods of Lithuanian intelligence worth underlining are the facts revealed, the method being the informational exploitation of Lithuanians, by reservists. Lithuanian agents operating in this area start fraternising with non-commissioned officers and privates who are (thanks to the last year of such a privilege) on open-ended leave. And then Lithuanian agents either acquire information directly or take advantage of limited cross-border traffic in such a way that they get intelligence-related information from each reservist who came to Lithuania with a certified agricultural pass-book. ${ }^{97}$

The Lithuanians were particularly interested in the situation in cross-border areas. That is why the intelligence-related work was centred round, with a few exceptions, the area of DOK No III Grodno, and did not cross the Święcany-Vilnius-Grodno-Suwałki line. In the period 1929 to 1933, four Lithuanian espionage cells were operating in the Suwałki region, four around Święciany, and as many as eight around Vilnius, and five southwest of Vilnius. In the period 1934 to 1935, Lithuanian intelligence cells operated in Lomża (two cells), Augustów (one), Suwałki (one), Grodno (two), Maladzyechna (one), and in Vilnius (11). ${ }^{68}$

The situation did not change in subsequent years. To a large extent, Lithuanian intelligence was based on information acquired from soldiers. From the counter-intelligence report for the year 1935, we learn that: 'The number of soldiers sextupled, from one in 1934 to six in 1935, including, for the first time,

67 CAW, Oddział II Sztabu Generalnego, I.303.4.2630, Raport kontrwywiadowczy za rok 1933 Samodzielnego Referatu Informacyjnego DOK III z kwietnia 1934 r. [Counter-Intelligence Report for 1933 of the Independent Information Office of DOK III of April 1934], pp. 9-10.

${ }_{68}$ RGWA-CPH-DK, fond 308, description 7, vol. 55, Opracowanie Oddziału II Sztabu Głównego „Wywiady obce w Polsce. Część I. Ogólne wiadomości o działalności wywiadów obcych w Polsce w okresie 1929-1935 [A Study of the Second Department of the General Staff 'Foreign intelligences in Poland. Part I. General information on the Operations Carried out by Foreign Intelligence in the Period 1929-1935]. 
a retired commissioned officer. Three out of six are privates, fugitives. ${ }^{69}$ Three Lithuanian espionage-related cases result from detaining fugitives from their own troops who supplied Lithuanian intelligence with information on their original troops. ${ }^{70}$

The report for the year 1936 noted that in 1936, in the area of DOK number III, 44 espionage-related affairs were liquidated with 63 people, out of which what was attributable to Lithuanian intelligence were eight affairs with 14 people. ${ }^{71}$ It was underlined that:

Lithuanian spies, Polish citizens, are recruited almost exclusively from among members of the Union for the Liberation of Vilnius, ${ }^{72}$ playing a role for Lithuanian intelligence identical to the one played by the Communist Party of Poland for Soviet intelligence. Being to a great degree dominated by the ZWW, most Lithuanian youth constitutes an inexhaustible source, for both the ZWW and also for Lithuanian intelligence, of agents and of information [...] The Lithuanian intelligence network in this area is not complex. Apart from the network of agents-residents, Lithuanian intelligence boasts in our terrain a very dense network of informers working free of charge, with informers usually being Lithuanian princes, students at Stefan Bathory University ${ }^{73}$ in Vilnius, male and female teachers in schools for Lithuanian minorities, pupils in the higher grades in Lithuanian gymnasiums in Vilnius and Święciany, and members of legal and illegal Lithuanian organisations [...] it was stated that the administration of the Lithuanian Students' Union of Stefan Bathory University in Vilnius is in possession of an up-to-date list of names of recruits and soldiers-Lithuanians already doing their compulsory military service in the army. The data for these lists, surnames, first names and assignments, is provided to the Lithuanian Students' Union of Stefan Bathory University by the administration of the troops of the Lithuanian St Christopher Association, and by directors of Lithuanian reading rooms. The students doing their military service and the Lithuanian intelligentsia are ordered by the Temporary Lithuanian Committee to concentrate soldiers-Lithuanians, mainly villagers, into 'unofficial' circles in the area in which they are doing their military service. Recruits-Lithuanians, properly formed before recruitment, after

${ }^{69}$ CAW, Oddział II Sztabu Generalnego, I.303.4.2630, Raport kontrwywiadowczy za rok 1935 Samodzielnego Referatu Informacyjnego DOK III, pp. 8-9.

70 Ibidem, p. 18.

71 CAW, Oddział II Sztabu Generalnego, I.303.4.2630, Raport roczny K.W. za rok 1936 [An Annual Report of Counter-Intelligence for 1936] Samodzielnego Referatu Informacyjnego DOK III, p. 1.

72 Hereinafter also referred to as ' $Z W W$ '.

${ }^{73}$ Vilnius University, then called Stefan Bathory University. 
joining the army, carefully watch the organisation and the course of military service, equipment, training programmes, the personnel of headquarters, and autumn exercises. They constantly keep in touch (personally, which implies leave, and correspondence-wise) with members of the ZWW, and simultaneously with members of the Lithuanian Students' Union of Stefan Bathory University in Vilnius, and they transfer the acquired military secrets to the latter, with those students in turn passing the information obtained to Lithuanian intelligence. What applies at this point are affairs liquidated by the Independent Information Office of Corps District Command No III of Corporal Szymkunas, shot in 1931; Sergeant Kołacz, sentenced in 1931 to eight years in prison; Bombardier Litwinowicz Michał, shot in 1932; Bombardier Bakanowski Józef, shot in 1933; the affairs of the students of Stefan Bathory University: Żołdak's ${ }^{74}$ Łukjański's, liquidated in 1935, the affair of Balulis, a teacher in the Lithuanian school, the affair being liquidated in 1935, and many others. Some Lithuanians, members of the WFPW ${ }^{75}$ organisation, also constitute a source of information for Lithuanian intelligence. Lithuanian intelligence is directly interested in learning about the following:

- garrisons bordering Lithuania (Suwałki, Augustów, Białystok, Grodno, Lida (due to five air regiments), Vilnius, Naujoji Vilnia and Nowe Święciany; units of the KOP from the personnel of the 'Grodno' and 'Wilno' brigades;

- organisations for civil defence training (POW, Strzelec, Krakus);

- Polish socio-cultural organisations in the Vilnius region, the Grodno region and the Suwałki region;

- Lithuanian emigré organisations into which Lithuanian intelligence puts provocateurs to control and then dismantle the organisations from within.

Furthermore, in this area, Lithuanian intelligence is laying the grounds for subversive underground rebellion organisations, which, at the right moment, could stab us in the back. ${ }^{76}$

Officers of Polish counter-intelligence stressed the fact that, as far as watching the Polish army was concerned, there was:

74 Kazimierz Żołdak, a communist and at the same time a Lithuanian spy arrested by the Independent Information Office of DOK number III. CAW, Oddział II Sztabu Generalnego, I.303.4.2630, Raport roczny K.W. za rok 1936 Samodzielnego Referatu Informacyjnego DOK III, p. 54.

75 This abbreviation stands for the National Office of Physical Education and Civil Defence Training.

76 CAW, Oddział II Sztabu Generalnego, I.303.4.2630, Raport roczny K.W. za rok 1936 Samodzielnego Referatu Informacyjnego DOK III, pp. 50-52. 
Cooperation between Lithuanian intelligence and the USSR, supplanting that between Lithuanian and German intelligence, which in turn remained operative until the Lithuanian-German conflict over Klaipeda. ${ }^{77}$ For this reason, the direct interests of Lithuanian intelligence are centred around the Polish-Lithuanian border; however, the cooperation between Lithuanian and Soviet intelligence means that Lithuanian intelligence, via its agents and informers, collects indisputable information, which is then passed on to Soviet intelligence, with the information being collected from all areas across which its agents and informers are scattered, that is, both from the Polish-Lithuanian border and from the interior of Poland; for instance, from garrisons in which Lithuanian soldiers are serving. This circumstance means that entities interested in combating Lithuanian intelligence are all corps districts which had Lithuanians in its troops [...] This year, I stated that Lithuanian intelligence encounters major difficulties in running intelligence operations, which applies to, say, the garrison of Vilnius. The recently employed method of systematically deploying Lithuanian recruits in military units situated in the interior of the Republic made Lithuanian intelligence lose the ability to expose its own troops from within, especially in Vilnius. ${ }^{78}$

In the last few years before the outbreak of the war, Lithuanian intelligence 'kept around Polish borders some agents "solicitors", whose task was to get across to Lithuania reservists returning from the army after completing either their respective compulsory military service or military exercises by the reserve force, after all of which they are entitled to a reward amounting to 80 litas for a non-commissioned officer and 50 litas for a private. ${ }^{79}$ After collecting information from fugitives, Lithuanians trained them and deployed them in Latvia, and thence they returned to Poland as agents of Lithuanian intelligence. ${ }^{80}$

It was also noted that Lithuanian intelligence started "applying the "chain" method in the organisation of residents in military units, with the method consisting in that the military resident who was finishing being on actual duty was obliged, in order to maintain the continuity of the reconnaissance of a given unit, to recruit his successor from a younger year group and make him stay in the troops. ${ }^{81}$

77 Ibidem, p. 54.

78 Ibidem, pp. 55-56.

79 RGWA-CPH-DK, fond. 308, description 7, vol. 60, Szefostwo Wywiadu Korpusu Ochrony Pogranicza. Raport kontrwywiadowczy za rok 1937. Cz. I. Szpiegostwo obce w pasie ochrony KOP i własna kontrakcja [The Administration of the Intelligence of the Border Protection Corps. A Counter-Intelligence Report for 1937. Part I: Foreign Espionage in the Protective Belt of KOP and Counter-Activity], p. 69.

80 Ibidem, p. 70.

81 Ibidem. 
However, there is no document to indicate the number of Lithuanians who did their mandatory service in the Polish army in the period 1923 to 1939.

Assuming that, on an annual basis, 300 young Lithuanians were conscripted, it is easy to calculate that such training might apply overall to 5,000 Lithuanians. Each of them could potentially constitute a source of valuable information for Lithuanian intelligence.

The Polish-Lithuanian intelligence war that waged in the period 1920 to 1930 is still relatively little explored. In Polish historiography, we can find only a few valuable publications which devote attention to the subject. This state of affairs is understandable. For several dozen years, there has been no access to the material of the Second Department of the General Staff of the Polish army. The situation in Lithuania looks similar, where the Soviet authorities disabled access to archival materials generated by the Lithuanian special services in the interwar period. However, there is no shadow of doubt that investigating this topic is important, not only for epistemic reasons, but also for practical ones, in order to understand what hindered all the attempts to normalise the relationship between interwar Poland and Lithuania, and why both states literally erected a barrier between each other, the symbols of which, right up to 1938, were removed railway tracks and broken roads, now covered in volunteers, grass, moss and weeds.

References:

\section{Sources:}

Centralne Archiwum Wojskowe, Oddział II Sztabu Generalnego,

Российский Государтьенный Военный Архив (Rosyjskie Państwowe Archiwum Wojskowe RGWA), Центр Хранения Историко-Документальных Коллекции (Centrum Przechowywania Historyczno-Dokmentalnych Kolekcji - (CPH-DK) w Moskwie:

- fond 308 , opis 4 , tom 19 ,

- fond 308 , opis 4 , tom 108 ,

- fond 308, opis 7, tom 55 ,

- fond 308 , opis 19 , tom 12 ,

- fon 460, opis 1 , tom 107.

- Rocznik oficerski 1923, Warszawa, 1923.

- Wojsko litewskie. Opracował Oddział II Sztabu Generalnego, Warszawa, 1925.

\section{Studies:}

Anušauskas Arvydas, Lietuvos slaptosios tarnybos (1918-1940), Vilnius 1993.

Anušauskas Arvydas, Lietuvos žvalgyba 1918-1940, Vilnius 2014.

Budrys Jonas, Kontržvalgyba Lietuvoje, New York 1967.

Ćwięk Henryk, Zarys działalności wywiadu litewskiego na polskim pograniczu w latach trzydziestych, Warszawa 1994. 
Dominiczak Henryk, Granica wschodnia Rzeczypospolitej Polskiej w latach 1919-1939, Warszawa 1992.

Gajownik Tomasz, Tajny front niewypowiedzianej wojny. Działalność polskiego wywiadu wojskowego na Litwie w latach 1921-1939, Warszawa 2010.

Informator o zasobie archiwalnym Centralnego Archiwum Wojskowego. Praca zbior. pod red. Natalii Bujniewicz, Warszawa 2008.

Jabłonowski Marek, Prochwicz Jerzy, Wywiad Korpusu Ochrony Pogranicza 1924-1939, Warszawa 2002/2003.

Kopczyk Henryk, Niemiecka działalność wywiadowcza na Pomorzu 1920-1933, Gdańsk 1970.

Kozaczuk Władysław, Bitwa o tajemnice. Służby wywiadowcze Polski i Rzeszy Niemieckiej 1922-1939, Warszawa 1977.

Lietuvos kariuomenés karininkai 1918-1953, T. I-X, Vilnius 2001-2015.

Łossowski Piotr, Kłajpeda kontra Memel. Problem Kłajpedy w latach 1918-1939-1945, Warszawa 2007.

Łossowski Piotr, Konflikt polsko-litewski 1918-1920, Warszawa 1996.

Łossowski Piotr, Po tej i tamtej stronie Niemna. Stosunki polsko-litewskie 1883-1939, Warszawa 1985.

Łossowski Piotr, Stosunki polsko-litewskie 1918-1920, Warszawa 1966.

Łossowski Piotr, Stosunki polsko-litewskie 1921-1939, Warszawa 1997.

Makowski Bronisław, Litwini w Polsce 1920-1939, Warszawa 1986.

Misiuk Andrzej, Służby specjalne II Rzeczypospolitej, Warszawa 1998.

Nałęcz Tomasz, Polska Organizacja Wojskowa 1914-1918, Wrocław-Warszawa-Kraków-GdańskŁódź 1984.

Pepłoński Andrzej, Kontrwywiad II Rzeczypospolitej, Warszawa 2002.

Pepłoński Andrzej, Wywiad a dyplomacja II Rzeczypospolitej, Toruń 2004.

Rezmer Waldemar, Litwini w Wojsku Polskim 1920-1939, w: Od armii komputowej do narodowej. T. II: Dzieje militarne Polski i jej wschodnich sąsiadów od XVI do XX wieku. Pod red. Macieja Krotofila i Aleksandra Smolińskiego, Toruń 2005, s. 253-266.

Skóra Wojciech, Działalność gdańskiej ekspozytury polskiego wywiadu wojskowego w latach 19201930 (Pomorze Zachodnie, Prusy Wschodnie i Wolne Miasto Gdańsk), Poznań 2011.

Skóra Wojciech, Pierwsze lata działalności polskiego wywiadu wojskowego w Wolnym Mieście Gdańsku (1920-1925), „Zapiski Historyczne” 2005, z. 1, s. 55-65.

Skóra Wojciech, Służba konsularna Drugiej Rzeczypospolitej. Organizacja, kadry i działalność, Toruń 2006.

Skóra Wojciech, Wspótpraca polskiego wywiadu z placówkami Ministerstwa Spraw Zagranicznych (1921-1923), „Przegląd Historyczno-Wojskowy” 2005, nr. 1, s. 109-126.

Sztab Generalny (Glówny) Wojska Polskiego 1918-2003. Red. Tadeusz Panecki, Franciszek Puchała, Jan Szostek, Warszawa 2003.

Szymanowicz Adam, Na tajnym froncie polsko-niemieckim. Polski wywiad w Prusach Wschodnich 1918-1939, Gdynia 2013.

Widacki Jan, Wywiad litewski w latach trzydziestych XX wieku jako przeciwnik wywiadu Korpusu Ochrony Pogranicza, ,Wojskowy Przegląd Historyczny” 1995, nr. 3-4, s. 85-94. 


\section{Waldemar Rezmer}

\section{KOBIETY I ŻOŁNIERZE W POLSKO-LITEWSKIEJ WOJNIE WYWIADÓW 1920-1939 \\ Streszczenie}

Po zakończeniu jesienią 1920 r. krwawych walk, konflikt polsko-litewski nie wygasł, lecz trwał, ale teraz główną arena zmagań stała się dyplomacja, propaganda i działania służb specjalnych: akcje dywersyjno-sabotażowe, dywersja propagandowa, dezinformacja i działania wywiadowcze. Ze strony polskiej prowadzone były przez agendy Oddziału II Sztabu Generalnego (Sztabu Głównego) Wojska Polskiego, ze strony litewskiej przez Oddział Wywiadowczy (Informacyjny) Sztabu Generalnego (Sztabu Najwyższego). Specyfiką litewskiego wywiadu skierowanego przeciwko Polsce było duże angażowanie kobiet i wykorzystywanie Litwinów - obywateli Rzeczypospolitej odbywających obowiązkową służbę w Wojsku Polskim. Największe klęski polskiego wywiadu były dziełem kobiet agentek litewskiego wywiadu. 